\title{
Nonbreeding-Season Drivers of Population Dynamics in Seasonal Migrants: Conservation Parallels Across Taxa
}

\section{Facteurs hors reproduction intervenant sur la dynamique des populations de migrateurs saisonniers : analogie entre divers taxons}

\author{
$\underline{\text { Anna M. Calvert }}^{1}, \underline{\text { Sandra J. Walde }}^{1}{\text {, and } \underline{\text { Philip D. Taylor }}^{2}}^{2}$
}

\begin{abstract}
For seasonal migrants, logistical constraints have often limited conservation efforts to improving survival and reproduction during the breeding season only. Yet, mounting empirical evidence suggests that events occurring throughout the migratory life cycle can critically alter the demography of many migrant species. Herein, we build upon recent syntheses of avian migration research to review the role of non-breeding seasons in determining the population dynamics and fitness of diverse migratory taxa, including salmonid fishes, marine mammals, ungulates, sea turtles, butterflies, and numerous bird groups. We discuss several similarities across these varied migrants: (i) non-breeding survivorship tends to be a strong driver of population growth; (ii) non-breeding events can affect fitness in subsequent seasons through seasonal interactions at individual- and population-levels; (iii) broad-scale climatic influences often alter non-breeding resources and migration timing, and may amplify population impacts through covariation among seasonal vital rates; and (iv) changes to both stationary and migratory non-breeding habitats can have important consequences for abundance and population trends. Finally, we draw on these patterns to recommend that future conservation research for seasonal migrants will benefit from: (1) more explicit recognition of the important parallels among taxonomically diverse migratory animals; (2) an expanded research perspective focused on quantification of all seasonal vital rates and their interactions; and (3) the development of detailed population projection models that account for complexity and uncertainty in migrant population dynamics.
\end{abstract}

RÉSUMÉ. À cause des contraintes logistiques, les efforts de conservation des migrateurs saisonniers se limitent souvent à l'augmentation du taux de survie et du succès de reproduction durant la saison de reproduction. Pourtant, des indices de nature empirique de plus en plus nombreux semblent indiquer que les évènements se produisant tout au long du cycle migratoire peuvent influencer grandement l'abondance de bon nombre d'espèces migratrices. Cet article présente une synthèse des recherches sur la migration aviaire afin de réviser le rôle des saisons hors reproduction dans la détermination de la dynamique des populations et du degré d'adaptation de différents taxons migrateurs, dont les Salmonidés, les mammifères marins, les Ongulés, les tortues marines, les papillons et de nombreux groupes d'oiseaux. Nous traitons de plusieurs similitudes entre ces divers migrateurs : (i) la survie hors reproduction a tendance à avoir une grande influence sur la croissance de la population; (ii) les évènements hors reproduction peuvent influencer le degré d'adaptation au cours des saisons subséquentes en raison des interactions saisonnières à l'échelle de l'individu et de la population; (iii) les conditions climatiques à grande échelle affectent souvent les ressources hors nidification et la phénologie de la migration, et peuvent amplifier les impacts sur les populations à cause de la covariance des taux vitaux saisonniers; (iv) les changements relatifs aux milieux fréquentés, tant pendant la période de reproduction qu'en dehors de celle-ci, peuvent avoir des conséquences importantes sur l'abondance et la tendance des populations. Enfin, nous émettons les recommandations

${ }^{1}$ Department of Biology, Dalhousie University, ${ }^{2}$ Biology Department, Acadia University, Canada

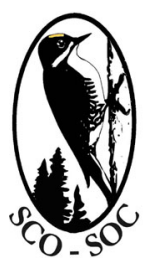

Sponsored by the Society of Canadian Ornithologists and Bird Studies Canada

Parrainée par la Société des onithologistes du Canada et Études d'oiseaux Canada

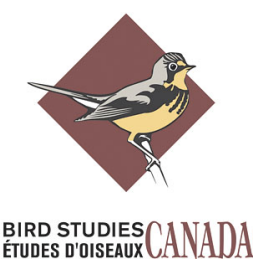


qui suivent car nous croyons que la recherche en conservation sur les migrateurs saisonniers en profitera : (1) reconnaître les analogies existant entre les animaux migrateurs de différents taxons; (2) orienter la recherche sur la quantification de tous les taux vitaux saisonniers et de leurs interactions; et (3) élaborer des modèles de projection de populations détaillés qui tiennent compte de la complexité et de l'incertitude inhérentes à la dynamique des populations migratoires.

Key Words: carry-over; demography; migration; nonbreeding; seasonal interaction; survivorship

\section{INTRODUCTION}

It is well understood that demographic fluctuations of populations living in seasonal environments are driven by events that occur throughout the year (Thompson 1959, Lack 1968, Fretwell 1972, Buehler and Piersma 2008). Variation in vital rates (growth, births, deaths) among seasons, and interactions between them may be particularly relevant to the population dynamics of "seasonal migrants" (Fig. 1), where individuals are exposed to multiple, and potentially divergent, environmental conditions in geographically separated habitats. Indeed, trade-offs between seasonal/geographic fitness costs and benefits led to the evolution of migratory behavior itself (Appendix 2). Although explicit recognition of seasonal effects is necessary for a complete assessment of the dynamics of any population, logistical constraints have often limited knowledge and conservation efforts for longdistance migrants to the breeding season only.

The importance of "nonbreeding events" to the conservation of migratory populations is becoming clearer as many face increasing rates of anthropogenically-induced environmental change. Current problems include disturbances to songbird wintering grounds (e.g., Robbins et al. 1989), depletion of critical stopover fuel sources for shorebirds (e.g., Baker et al. 2004), damming of rivers used by migrating fishes (e.g., Ratner et al. 1997), and disruption of ungulate migration routes (e.g., Bolger et al. 2008). Among migratory birds, conditions encountered in nonbreeding habitats have been linked to changes in abundance (Sherry et al. 2005), to reproduction (Norris et al. 2004a, Drent et al. 2006), and to persistence of declining populations (Robbins et al. 1989, Moore et al. 1995, Baker et al. 2004). Events outside of the breeding season may have been major contributors to population decline for migratory reptiles (Crowder et al. 1994), for fish (Wilson 2003), for ungulates
(Bolger et al. 2008), and for marine mammals (Kraus et al. 2005). Climatic changes (IPCC 2007) are also altering nonbreeding habitats, reducing migrants' physical preparedness for breeding (Friedland 1998, Bairlein and Huppop 2004, Ward et al. 2005), and leaving their reproductive phenology out of synch with food availability (Stenseth and Mysterud 2002, Drent et al. 2003, Both et al. 2006).

Migratory species belonging to very different taxonomic groups face parallel challenges in coping with change occurring in multiple habitats, and we argue that an increased awareness of these parallels will not only help to guide research efforts for particular taxa, but has the potential to help improve the effectiveness of conservation efforts. Here, we build upon recent syntheses of seasonal avian migration (e.g., Norris 2005, Dingle 2006, Newton 2006) to review (i) the role of nonbreeding survival in population dynamics of migrants, (ii) the impacts of nonbreeding events on subsequent reproduction and survival, and (iii) the consequences of these effects for population abundance and persistence, both generally and in relation to changing climatic conditions. Overall, we highlight the relevance of migratory bird research to studies of other migrants (see also Martin et al. 2007, Bolger et al. 2008, Robinson et al. 2008, Sherrill-Mix et al. 2008), and make specific recommendations for the incorporation of seasonal dynamics into conservation research and planning for migratory species.

\section{DEMOGRAPHIC ROLE OF THE NONBREEDING SEASON}

Ideally, the demographic importance of events during each season should be evaluated by incorporating the variation in vital rates throughout the life cycle into a model of population growth, and estimating the sensitivity of population dynamics to 
Fig. 1. Schematic illustration of parallel migratory life histories across diverse migratory taxa, and the common names given to each seasonal life cycle phase; nonbreeding seasons are shaded in grey. Note that in cases where mating occurs during "nonbreeding" seasons (e.g., some mammals), the "breeding" season refers to the birthing season. Diagram is not to scale.

Birds

\begin{tabular}{|l|l|l|l|l|}
\hline Breeding & Fall migration, stopover & Wintering & Spring migration, stopover & Breeding \\
\hline
\end{tabular}

Salmonids

\begin{tabular}{|l|l|l|l|l|}
\hline Spawning & Downstream migration & Ocean feeding, growth & Return migration & Spawning \\
\hline
\end{tabular}

Butterflies

\begin{tabular}{|l|l|l|l|l|}
\hline Breeding & Fall migration & Wintering & Spring migration & Breeding \\
\hline
\end{tabular}

Marine mammals

\begin{tabular}{|l|l|l|}
\hline Calving & Ocean feeding, migrations & Calving \\
\hline
\end{tabular}

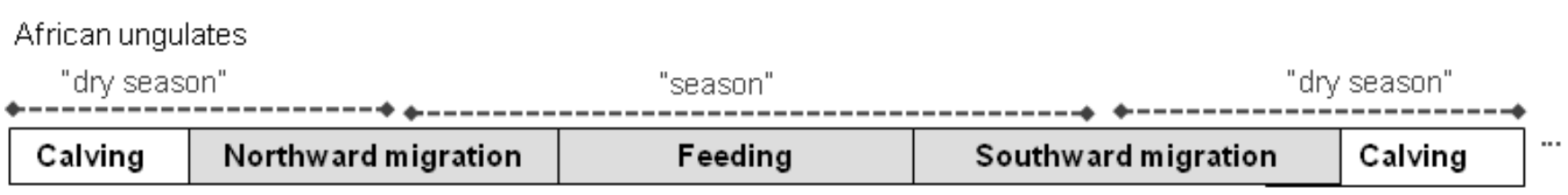

Sea turtles

\begin{tabular}{|l|c|c|c|}
\hline Nesting & Ocean feeding, growth & Return migration & Nesting \\
\hline
\end{tabular}

changes in seasonal parameters (Caswell 2001). Although birth and death rates are widely available for the breeding-season, estimates of vital rates have rarely been obtained for the nonbreeding season, and even less often over several consecutive seasons. In this section we begin by comparing nonbreeding demographic parameters among various taxa and by discussing their probable contributions to population growth. We then review the evidence for influences of nonbreeding events on subsequent survival or reproduction at two scales: individual-level "seaso nal interactions", e.g., "carry-over" of a migrant's physical condition or migratory timing onto subsequent fitness; and population-level seasonal interactions, e.g., "density-dependence" during one or more seasons. Finally, we discuss the particular relevance of nonbreeding events in the context of current climatic change.

\section{Nonbreeding demography}

Nonbreeding survival and mortality

The principal sources of nonbreeding mortality are similar across migratory taxa: predation, extreme weather events, and habitat destruction or alteration. 
Predation is the key mortality factor for migrating caribou and elk, for salmonids during their nonbreeding marine phase, and for sea turtle hatchlings during their first oceanic journey (Bergerud and Elliot 1986, Hansen and Quinn 1998, Hebblewhite and Merrill 2007, Harewood and Horrocks 2008). Weather conditions also influence survival, especially during migration (Newton 2007): storm events often result in high mortality for migrating birds (Butler 2000, Jones et al. 2004), and extreme fluctuations in temperature or precipitation reduce survival for both birds and fish (e.g., Möller 1989, Hansen and Quinn 1998). Deterioration of habitats used during the nonbreeding season has been implicated in declines of passerines, fish, and mammals, and climatic factors may indirectly affect survivorship by altering nonbreeding habitat or food availability (e.g., Fryxell 1987, Mduma et al. 1999, Sillett et al. 2000).

Quantitative comparisons of nonbreeding mortality across taxa are not yet possible, due to differences in estimation technique or time frame. For instance, studies reporting high migration mortality in passerines, salmonids, and ungulates (Sillett and Holmes 2002, Kareiva et al. 2000 and Hebblewhite and Merrill 2007) used different methods and time intervals than studies finding low rates of migration mortality in passerines and waterfowl (Ketterson and Nolan 1982, Gauthier et al. 2001). Moreover, many of the available estimates of nonbreeding survivorship represent "apparent" survival, i.e., the annual return rate of individuals to a monitored site. Given that the broad geographic areas covered by long-distance migrants may result in underestimation of dispersal, such approximations will greatly overestimate actual mortality unless they account for site fidelity or emigration (e.g., Friedland et al. 1993, Ruggerone et al. 2003, Jones et al. 2004, but see Cilimburg et al. 2002).

Reliable seasonal demographic estimates should increase with novel statistical and technological developments (Table 1). For example, long-term programs of physical marking of migrants and associated quantitative modeling permit better measurement of seasonal survivorship (e.g., Gauthier et al. 2001, Table 1), and studies based at nonbreeding areas are improving estimates of stationary nonbreeding (i.e., winter) mortality (e. g., Marra and Holmes 2001, Madsen et al. 2002, Sillett and Holmes 2002). New statistical tools also permit the analysis of incomplete data, as well as the inclusion of information from one population in the modeling of another, by explicitly describing error and uncertainty terms (e.g., Bayesian integrated population models: Besbeas et al. 2002, Hoyle and Maunder 2004; or state-uncertainty mark-recapture models: Pradel 2005). Nonetheless, any permanent emigration of individuals from a study site would still bias survivorship estimates derived from these models, such that technological developments in the tracking of individuals across seasons may be required to further refine demographic estimates (e.g., satellite and radio tags; see Table 1).

Patterns of age-specific mortality during nonbreeding seasons are largely parallel across taxa, with juveniles typically experiencing high mortality during their first migratory journey. Between fledging and arrival at wintering grounds, young birds face elevated risks from predation (Anders et al. 1997), from unfavorable weather (van der Jeugd and Larsson 1998, Menu et al. 2005), from lack of experience orienting (Baldaccini and Bezzi 1989, Wiltschko and Wiltschko 2003), from competition (Woodrey 2000, Yong et al. 1998), or from harvest (Francis et al. 1992, Menu et al. 2002). Hatch-year birds may continue to experience poorer overwinter survival or reduced body condition prior to spring migration (Conroy et al. 1989, Perez-Tris and Telleria 2002). Juvenile salmonids experience similarly high mortality during their first migration and at sea prior to breeding (Friedland 1998, Greene and Beechie 2004, Quinn 2005), and young sea turtles (Crowder et al. 1994) and ungulates (Fryxell 1987, Fancy et al. 1994, Owen-Smith et al. 2005) also show lower survival than breeding adults. The extent to which potentially high natal dispersal biases these estimates is uncertain, as dispersal rates for all ages remain poorly quantified.

Taxonomic parallels in sex-biased seasonal survival are less obvious. Migratory behavior is often sexspecific in birds, including differences in stopover patterns (Yong et al. 1998), migration timing (Phillips et al. 2005, Kokko et al. 2006), and nonbreeding philopatry (Robertson and Cooke 1999), but the demographic consequences are largely unknown (Rankin and Kokko 2007). There is no consistent sex-bias in nonbreeding mortality, even among well-studied migrants (e.g., waterfowl: Raveling et al. 1992, Menu et al. 2002), but documented differences usually appear to favor males. For example, competition for winter habitat among warblers results in male-biased physical 
Table 1. Current tools used for the study of nonbreeding parameters in diverse seasonal migrant taxa and some of their applications.

\begin{tabular}{|c|c|c|c|}
\hline Method & Characteristic measured & $\begin{array}{l}\text { Taxonomic } \\
\text { group(s) }\end{array}$ & Studies \\
\hline
\end{tabular}

INTRINSIC MARKERS

Mitochondrial DNA
haplotypes

Microsatellite markers

Stable isotopes

Trace elements

Hormone levels

\section{INDIVIDUAL TRACKING}

Geolocator tags

Satellite tags

Passive integrated

transponder tags

Radio tags

Electronic data-log tags

Mark-recapture

Multi-state mark-recapture migratory connectivity

nonbreeding population structure ungulates; salmonids

nonbreeding social behaviour

nonbreeding habitat use

nonbreeding distribution, migratory connectivity

nonbreeding habitat impacts salmonids

passerines

marine fish

passerines
Lopes et al. 2006

Courtois et al. 2003, Fraser and

Bernatchez 2005

Fraser et al. 2005

Norris et al. 2004a, Hobson 2005

Campana et al. 1999

Marra and Holberton 1998 migratory connectivity, migration speed

migratory connectivity, population structure

nonbreeding distribution, critical sea turtles habitat

migration route, timing

inter-breeding intervals

post-fledging survivorship

migration routes and timing

nonbreeding distribution, migratory connectivity

seasonal nonbreeding survivorship

migratory stopover behaviour turtles

seabirds passerines Stutchbury et al. 2009

marine fish Block et al. 2005

James et al. 2005

waterfowl; sea Fox et al. 2003, Sherrill-Mix et al. 2008

sea turtles Saba et al. 2007

passerines Anders et al. 1997

ungulates Ferguson and Elkie 2004

marine fish; Hunter et al. 2004, Phillips et al. 2005

waterfowl; Gauthier et al. 2001, Sillett and Holmes passerines 2002

passerines Schaub et al. 2004, Calvert et al. 2009 


\section{METHOD COMBINATIONS}

Satellite tags, molecular markers

Stable isotopes, markrecapture

Remote sensing, markrecapture gene flow between migrants, residents

migratory connectivity, population structure

migratory connectivity, nonbreeding habitat

nonbreeding distribution ungulates

passerines

shorebirds

passerines
Boulet et al. 2007

Clegg et al. 2003

Gunnarsson et al. 2005

Szep and Möller 2005

\section{MODELING TOOLS}

Population projection models importance of nonbreeding survival

Geographic Information Systems

Habitat modeling

Evolutionary programming

Dynamic optimization modeling

Integrated population models

Dynamic state modeling critical nonbreeding habitat location

mapping of migration vs. shipping routes

predation risk to migrants vs. residents

importance of stopover habitat

habitat needs during migration

effectiveness of conservation strategies

nonbreeding links to population growth

effects of seasonal habitat change sea turtles; shorebirds

passerines; butterflies

marine mammals

ungulates

birds (general) Tankersley and Orvis 2003

ungulates

passerines

birds; marine mammals

waterfowl
Caswell 2001, Crowder et al. 1994, Calvert et al. 2006

Villard and Maurer 1996, Oberhauser and Peterson 2003

Firestone et al. 2008

Hebblewhite and Merrill 2007

Boone et al. 2006

Martin et al. 2007

Besbeas et al. 2002, Hoyle and Maunder 2004

Pettifor et al. 2000 condition, apparent survival, and sex ratio (Holmes et al. 1989, Sherry and Holmes 1996, Marra and Holberton 1998, Marra and Holmes 2001). Higher nonbreeding mortality among females is also apparent in some salmonids (Holtby and Healey 1990, Spidle et al. 1998) and whales (Fujiwara and Caswell 2001).

\section{Sensitivity of nonbreeding vital rates}

The "sensitivity" or "elasticity" (hereafter just "sensitivity") of vital rates is a measure of the contribution of each parameter to population growth, relative to all other rates over the life cycle. Theory predicts that long-lived "survival" species will be more sensitive to nonbreeding events, whereas short-lived "reproductive" species are more sensitive to breeding parameters (Saether et al. 1996, Heppell et al. 2000). Broad-scale comparisons indicate that population growth across a wide diversity of migrants is almost always more sensitive to adult survival, often a surrogate for nonbreeding survival, than to reproductive parameters (Pfister 1998, Saether and Bakke 2000). Indeed, high sensitivity of adult/nonbreeding survival has been demonstrated for seabirds 
(Cuthbert et al. 2001, Ezard et al. 2006), shorebirds (Hitchcock and Gratto-Trevor 1997, Calvert et al. 2006), waterfowl (Hoekman et al. 2006), songbirds (Fletcher et al. 2006), marine mammals (Brault and Caswell 1993, Caswell et al. 1999, Runge et al. 2004), ungulates (Fancy et al. 1994, Mduma et al. 1999), and salmonids (Greene and Beechie 2004). While breeding-season effects such as food limitation or predation likely also play an important role in population regulation, particularly for the shorter-lived species (Saether et al. 1996, Heppell et al. 2000), threats to survival outside the breeding season thus appear to have strongly impacted the populations dynamics of migrants studied to date.

\section{Cross-seasonal nonbreeding effects}

\section{Individual-level seasonal interactions}

Whereas vital rates are estimated at the scale of the population, migration is accomplished by individual animals, and the experiences of an individual in one season thus inevitably affect its subsequent fitness (Dingle 1996, Newton 2004, Norris 2005). Although in the long-term there must theoretically be trade-offs between different vital rates (see McNamara and Houston 2008 and references therein), these individual-level seasonal interactions, sometimes termed "carry-over effects", generate short-term positive correlations among consecutive vital rates (Figs. 2,3) and have become the focus of several studies on the fitness consequences of nonbreeding events in migratory birds (Norris 2005, Runge and Marra 2005). Specifically, differential winter habitat use was shown to alter the physiological condition of passerines prior to spring migration (Marra and Holberton 1998, Bearhop et al. 2004), an effect which can subsequently influence migration phenology (Saino et al. 2004), reproductive success (Norris et al. 2004a), and survival (Marra and Holmes 2001). Similarly, individual experiences during migratory travel or stopover may further influence subsequent fitness (Fig. 2, Table 2). Prebreeding resources are particularly essential to female reproductive success and survival of shorebirds and waterfowl (Alisauskas 2002, Drent et al. 2006, Kéry et al. 2006).

Individual-level seasonal interactions are not unique to migratory birds (Table 2). Survival and reproduction of salmonids, for instance, are strongly influenced by previous climate- and competition-driven variation in ocean-phase growth (Ruggerone et al. 2003, Beamish et al. 2004, Friedland et al. 2005). Migratory ungulates probably also experience seasonal interactions in a manner parallel to that seen in birds, yet these remain little studied (Bolger et al. 2008). Given that individual correlations can persist for multiple seasons or even years (Pienkowski and Evans 1984, Marra and Holmes 2001), they merit incorporation into assessments of migratory population dynamics, particularly in taxa other than avian migrants (Doak et al. 2005, Runge and Marra 2005).

\section{Population-level seasonal interactions}

Seasonal interactions also operate at the level of the migratory population (Runge and Marra 2005, Figs. 2,3, Table 2). Since Fretwell's (1972) proposal that population size in the breeding season is driven by habitat availability in other seasons, growing evidence suggests that density-dependent factors during one season affect fitness parameters in later life stages for migratory birds (Ketterson and Nolan 1982, Dit Durell et al. 1997, Newton 2004, 2006). Density-dependent regulation across seasons, such as reduced fecundity with high breeder density (i. e., reflecting elevated prior survival or productivity; Sillett and Holmes 2005, Gunnarsson et al. 2006), could produce negative correlations between consecutive demographic traits for any seasonal migrant. A negative relationship between reproductive success and nonbreeding survivorship driven by limiting seasonal resources could then buffer overall abundance changes (Fig. 3). Regulation of avian migrant populations based on nonbreeding resources has been hypothesized a number of times (Robbins et al. 1989, Rappole and McDonald 1994, Buehler and Piersma 2008), but stronger empirical evidence is still needed to confirm impacts on survival and abundance (Latta and Baltz 1997, Sherry et al. 2005). Some nonavian migrants have also shown evidence of nonbreeding density dependence, but much empirical work is still needed (e.g., mammals: Bolger et al. 2008; salmonids: Greene and Beechie 2004, Quinn 2005).

The population dynamics of seasonal migrants depend upon the connections between breeding and nonbreeding populations (Esler 2000), and the strength of nonbreeding population regulation may vary with a population's "migratory connectivity" (Webster et al. 2002). The degree to which individuals from the same breeding area overlap in their nonbreeding distribution, and vice versa, is 
Fig. 2. Generalized schematic illustrating the influences of seasonal events on the population dynamics of seasonal migrants. Arrows represent direct seasonal fitness impacts (solid black arrows), crossseasonal interactions (dashed grey arrows), covariation in seasonal environments (solid grey arrows), and sensitivities of population growth to seasonal vital rates (dotted black arrows). Note that terminology applies generally to avian migrants, but concepts extend to all seasonal migrants (e.g., "winter" refers to any primarily stationary nonbreeding season). See Table 2 for definitions and literature examples of each seasonal influence and their links to population growth.
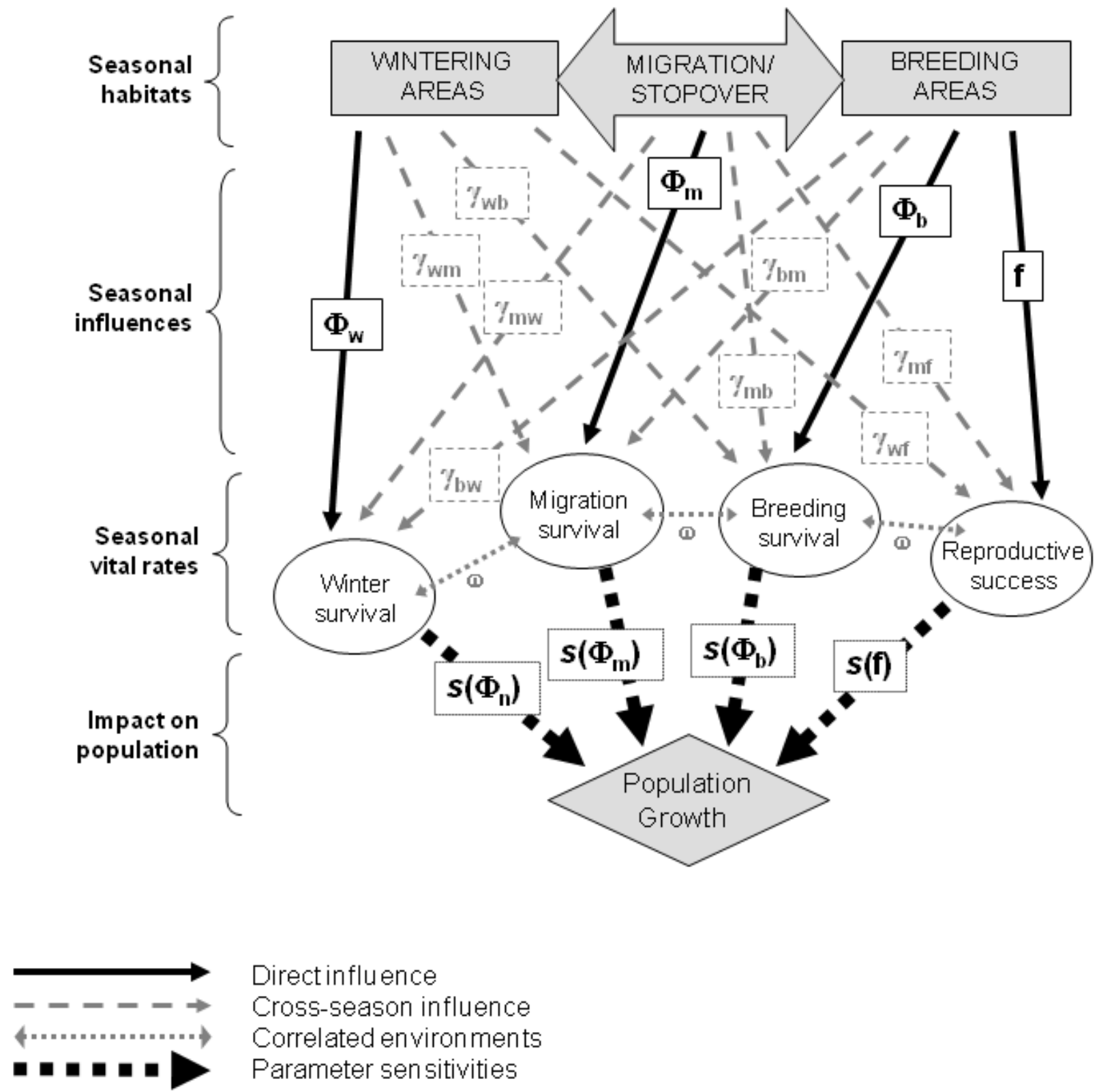
Fig. 3. Three levels of cross-seasonal nonbreeding influences upon population dynamics of seasonal migrants, illustrating the required nonbreeding characteristic, the subsequent season impact, and the consequences for population growth; linear relationships are assumed for simplicity, and each level is presented independently from others (i.e., without accounting for potential interactions among levels). At the individual level, carry-over of individual condition or migration timing from one season to another can result in short-term positive correlations among seasonal vital rates and between nonbreeding vital rates and population growth. At the population level, density-dependence in one season can cause negative relationships between seasonal vital rates which may buffer overall effects on population growth. At the environmental level, broad-scale climatic trends can cause positive covariation among seasonal environments and thus among consecutive seasonal vital rates, with the potential for magnified climatic impacts on population growth. See Table 2 and text for further details and literature examples.
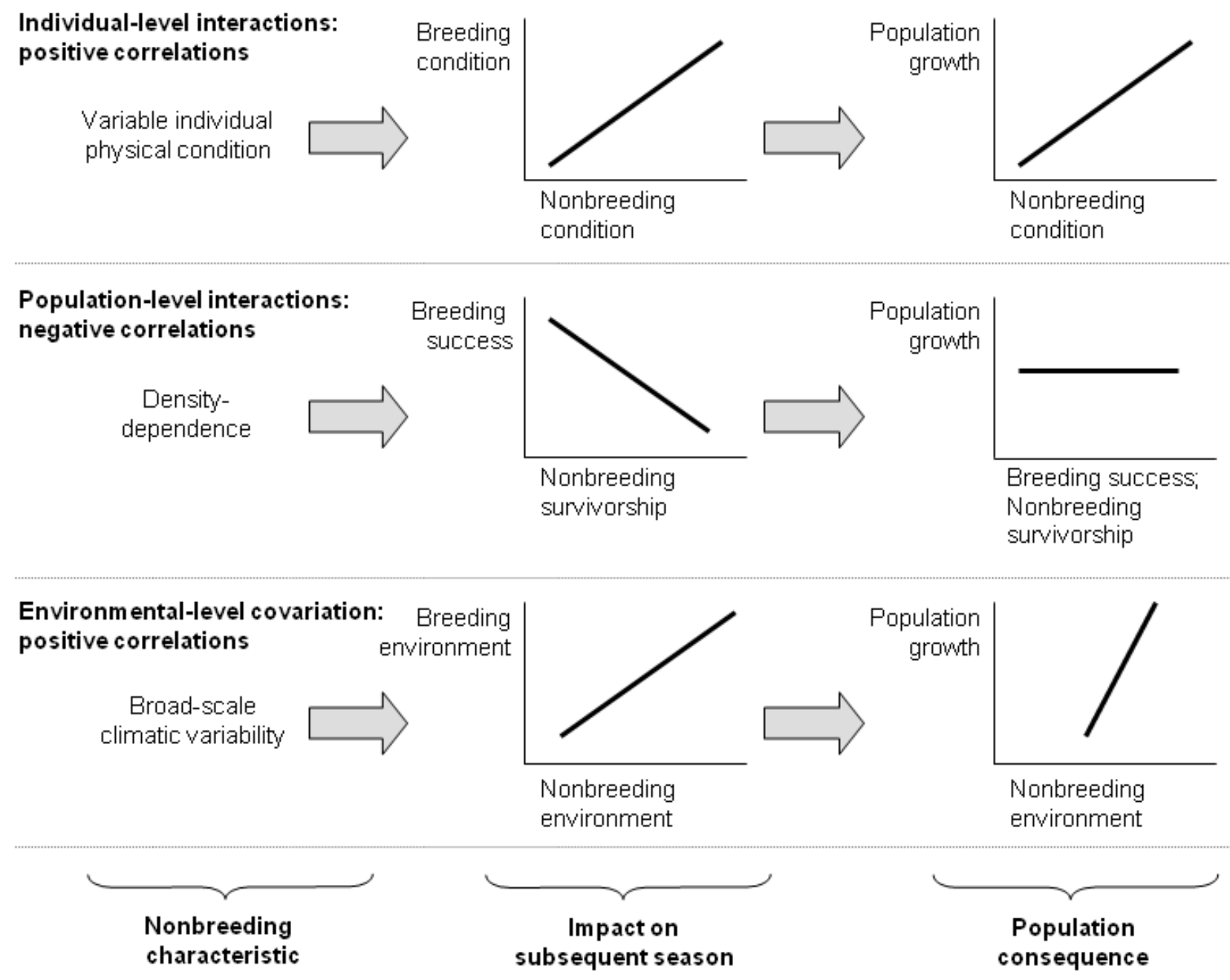
Table 2. Conceptual links between seasonal habitats and population growth for seasonal migrants, as shown in Figure 2, with a description of each link and the level of cross-season interactions (see Figure 3 ). Note that "winter" refers to any primarily-stationary nonbreeding season.

\begin{tabular}{|c|c|c|c|c|}
\hline Symbol & Parameter & & Description & Examples \\
\hline \multicolumn{5}{|c|}{ DIRECT FITNESS INFLUENCE } \\
\hline \multirow[t]{2}{*}{$\Phi_{\mathrm{w}}$} & Winter survivorship & magnitude & $\begin{array}{l}\text { age-dependent; influenced by } \\
\text { predation, habitat quality }\end{array}$ & $\begin{array}{l}\text { Conroy et al. 1989, Conway } \\
\text { et al. 1995, Marra \& Holmes } \\
2001\end{array}$ \\
\hline & & variance & $\begin{array}{l}\text { varies with environmental } \\
\text { conditions }\end{array}$ & $\begin{array}{l}\text { Mduma et al. 1999, Grosbois } \\
\& \text { Thompson 2005, Schaub et } \\
\text { al. 2005, Kéry et al. } 2006\end{array}$ \\
\hline \multirow[t]{2}{*}{$\Phi_{\mathrm{m}}$} & Migration survivorship & magnitude & $\begin{array}{l}\text { age-dependent; influenced by } \\
\text { habitat, energetic constraints }\end{array}$ & $\begin{array}{l}\text { Gauthier et al. 2001, Sillett } \\
\text { and Holmes 2002, Menu et al. } \\
2005\end{array}$ \\
\hline & & variance & $\begin{array}{l}\text { varies with environmental } \\
\text { conditions }\end{array}$ & $\begin{array}{l}\text { Friedland et al. 1993, Butler } \\
2000 \text {, Cuthbert et al. } 2001\end{array}$ \\
\hline$\Phi_{\mathrm{b}}$ & Breeding survivorship & & & \\
\hline $\mathrm{f}$ & Reproductive success & & & \\
\hline
\end{tabular}

\section{CROSS-SEASON FITNESS Level INFLUENCE}

$\gamma_{\mathrm{wm}} \quad$ Winter effect on individual, migration survivorship population

$\gamma_{\mathrm{wb}} \quad$ Winter effect on breeding individual, survivorship population

$\gamma_{\mathrm{wf}} \quad$ Winter effect on breeding individual, success

population

$\gamma_{\mathrm{mw}} \quad$ Migration effect on population winter survivorship

$\gamma_{\mathrm{mb}} \quad$ Migration effect on $\quad$ individual breeding survivorship $\gamma_{\mathrm{mf}} \begin{aligned} & \text { Migration effect on } \\ & \text { breeding success }\end{aligned}$ winter habitat competition affects survival during migration via individual body condition

availability of winter resources affects later survival via individual body condition, density dependence

availability of winter resources affects reproduction via individual condition, migration timing, densitydependence

climate-driven variation in resources at fall staging site influence overall (presumably winter) survival

availability of migration/stopover resources affects subsequent survival via individual body condition

availability of migration/stopover resources affects reproduction via individual condition, migration timing
Marra and Holmes 2001, Sillett \& Holmes 2002

Sherry \& Holmes 1996, Beamish et al. 2004, Friedland et al. 2005

Norris et al. 2004a, Newton 2004, Saino et al. 2004, Moore et al. 2005

Schaub et al. 2005

Schmutz \& Ely 1999, Baker et al. 2004, Kéry et al. 2006, Newton 2006

Alisauskas 2002, Mainguy et al. 2002, Drent et al. 2003, 2006, Reed et al. 2004 
$\begin{array}{ll}\gamma_{b w} & \begin{array}{l}\text { Breeding effect on winter individual } \\ \text { survivorship }\end{array}\end{array}$

$\gamma_{\mathrm{bm}} \quad$ Breeding effect on individual migration survivorship juveniles from favourable breeding habitats are more likely to obtain access to good winter habitat

juveniles departing breeding grounds in poor weather, poor condition or late have lower migration survival
Dit Durell et al. 1997,

Gunnarsson et al. 2005

Menu et al. 2005

\section{CLIMATIC INFLUENCES}

$\omega$ Environmental covariation

broad-scale climatic variation across Sillett et al. 2000, Grosbois \& seasons results in covariation among Thompson 2005, Stenseth \& consecutive seasonal vital rates
Mysterud 2005, Lee et al. 2007

\section{SENSITIVITIES}

$s($ ) Sensitivity of population growth to seasonal vital rates population growth sensitivity to annual adult survival usually high; seasonal sensitivities poorly known
Caswell et al. 1999, Greene \& Beechie 2004, Calvert et al. 2006, Fletcher et al. 2006 likely to influence the relative importance of breeding and nonbreeding habitats on demographic fluctuations (Webster et al. 2002, Webster and Marra 2005). Interactions between breeding and nonbreeding events are likely to be amplified in populations with strong migratory connectivity, and thus its inclusion in population models will permit more effective evaluation of alternative conservation strategies (e.g., Martin et al. 2007). Migratory connectivity has now been studied in numerous avian migrants through the use of new tools such as genetic markers and stable isotopes (e.g., Clegg et al. 2003, Lopes et al. 2006, Table 1). Similarly, tracking of individual fish has allowed divergent breeding populations to be distinguished during nonbreeding seasons (e.g., Campana et al. 1999, Hunter et al. 2004, Fraser and Bernatchez 2005), and the identification of seasonal population structuring is now gaining attention in other taxa (e.g., caribou: Boulet et al. 2007).

\section{Climatic impacts and correlations}

Migrants are exposed to environmental variation in several geographic areas, such that current climatic changes may magnify any nonbreeding season influences on population dynamics. Projected increases in the frequency of extreme weather (IPCC 2007) might increase direct mortality during migratory travel (Butler 2000, Newton 2007), and could further affect subsequent survival and/or reproduction via individual- or population-level seasonal interactions. Nonbreeding survival of migrants fluctuates strongly in response to environmental conditions (Friedland et al. 1993, Frederiksen et al. 2005), and the omission of true (process) variance from population analyses could lead to inaccurate estimates of growth rate or population viability (Beissinger and Westphal 1998, Caswell 2001) and misleading assessments of the status of migratory species (Hitchcock and Gratto-Trevor 1997, Gaillard et al. 2000, Cuthbert et al. 2001). Future climatic change may increase variability in migrants' nonbreeding survival and thus alter population trajectories (Friedland et al. 2005, Grosbois and Thompson 2005, Laaksonen et al. 2006), as the ability of migrants to adapt to climatic changes remains uncertain (Lemoine and Bohning-Gaese 2003, Bêty et al. 2004, Both et al. 2005, Appendix 2).

Climatic effects also have the potential to elicit rapid population change through positively correlated vital rates (Lee et al. 2007, Fig. 3), as broad-scale climatic variation can affect local weather, and hence seasonal vital rates, across several consecutive seasons (Sillett et al. 2000, Stenseth and Mysterud 2005). Indeed, there is evidence of covariation in vital rates both within and among 
populations (Schaub et al. 2005, Ezard et al. 2006), with implications for parameter sensitivities and population trajectory (Doak et al. 2005, Adahl et al. 2006). Together with individual- and population-level seasonal interactions, "environme ntal-level covariation" among vital rates may thus drive complex relationships between nonbreeding seasons and population dynamics (Holmes 2007, Figs. 2,3, Table 2).

Recent climatic shifts have produced parallel responses among migratory taxa during the nonbreeding season (Robinson et al. 2008). Changes in the temperature/precipitation regime of nonbreeding sites are leading to altered timing of migration and breeding (Cotton 2003, Sims et al. 2004, Gunnarsson et al. 2006), and to changes in reproductive rates for many migrant species (e.g., Stenseth and Mysterud 2002, Weishampel et al. 2004, Lehikoinen et al. 2006, Table 3). The reproductive success of migratory birds breeding in both Europe and North America is also being shaped by climate-driven fluctuations in nonbreeding food availability (Saino et al. 2004, Ward et al. 2005, Laaksonen et al. 2006), while reproductive output in sea turtles fluctuates with broad-scale ocean cycles (Saba et al. 2007). Continued shifts in climate could further alter migration routes or geographic distribution (Sutherland 1998, Austin and Rehfisch 2005, Gauthreaux et al. 2005), and ultimately the capacity of nonbreeding habitats to sustain migratory populations (e.g., Oberhauser and Peterson 2003). The susceptibility of all seasonal migrants to major global climatic shifts (IPCC 2007) is thus further justification for cross-taxa conservation planning.

\section{DISCUSSION}

\section{Nonbreeding season relevance to population persistence}

The above sections confirm the relevance of nonbreeding events to seasonal vital rates, but growing evidence also supports longer-term consequences for the abundance and persistence of threatened migrant populations (Table 3, see also review by Robinson et al. 2008). En-route habitats are critical to maintaining positive population growth in landbirds (Hutto 2000, Mehlman et al. 2005, Table 3), and habitat change in the tropics may have contributed to the reduced breeding abundance of many species (Robbins et al. 1989, Rappole and McDonald 1994). The persistence of endangered whales and other migratory marine mammals is jeopardized by commercial shipping traffic (Runge et al. 2004, Kraus et al. 2005, Firestone et al. 2008), while fisheries bycatch during migration and ocean-foraging threatens declining seabirds (Phillips et al. 2005). Commercial harvesting of fish during nonbreeding seasons could precipitate declines if the migratory connectivity to breeding populations is unknown (Campana et al. 1999, Beacham et al. 2005). Finally, shorebirds that exploit specific habitats for intense refuelling periods are particularly sensitive, as seen with the sudden decline of the Red Knot (Calidris canutus) attributed to changing food availability at a critical spring stopover site (Baker et al. 2004, Skagan 2006).

The importance of nonbreeding season vital rates to population dynamics is not unique to migratory animals, and in fact many of the seasonal influences discussed above apply equally to the conservation of nonmigrant animals and plants, e.g., nonmigratory amphibians or insects that use different habitats as juveniles and adults. But seasonal migrants are unique in the geographic scale of these differences, leaving them vulnerable to changes in several distant habitats as well to factors that might interrupt migratory travel. Globally, large-scale ungulate migrations are increasingly cut off by agricultural development and other anthropogenic habitat change (Berger 2004, Bolger et al. 2008), and entanglement of sea turtles in fisheries gear impedes breeding-based conservation efforts (Crowder et al. 1994, James et al. 2005). Reduced juvenile-to-spawner survival of salmon in estuarine and marine areas (Wilson 2003) has been linked to changing ocean climate conditions (Friedland et al. 1993, Hansen and Quinn 1998), while birds around the world are experiencing changes to critical pre-breeding migration resources (Norris et al. 2004b, Drent et al. 2006). Human and climatic impacts on natural systems are of immediate concern to all seasonal migrants, where the success or failure of conservation actions may hinge upon identification of seasonal drivers of population change. As noted by Bolger et al. (2008) regarding knowledge gaps in the population dynamics of migratory ungulates, insight borrowed from other migratory taxa, well-studied birds in particular, may therefore be key to developing appropriate research plans and effective conservation strategies. 
Table 3. Examples of human-induced nonbreeding impacts on population dynamics of diverse seasonal migrants, as suggested by empirical studies.

\begin{tabular}{lll}
\hline \hline Nonbreeding season event & $\begin{array}{l}\text { Suggested population } \\
\text { impact }\end{array}$ & $\begin{array}{l}\text { Taxonomic } \\
\text { group(s) }\end{array}$ \\
\hline
\end{tabular}

\section{HABITAT CHANGE}

Tropical deforestation (winter habitat)

Coastal habitat destruction

Depletion of stopover food source

Loss of winter, staging habitat

Increase in agricultural development

River damming (breeding/ migration habitat)

Agricultural development and fencing

Human settlement, farming, fencing

\section{CLIMATIC VARIABILITY}

Change in winter climate

Increase in winter/spring temperature

Sudden weather changes, storms

Change in ocean temperature

Variation in dry-season rainfall decline in abundance

passerines

minor relative to other factors

passerines

decline in abundance

shorebirds

shorebirds

reduced survival, abundance

decline in abundance

waterfowl

increased migration survival waterfowl

reduced migration survival salmonids

disruption of metapopulation

decline in abundance

interruption of migration route

salmonids

ungulates

terrestrial mammals

fluctuations in abundance

improved survival, reproduction

mortality during migration

reduced nonbreeding survival

variation in breeding frequency

reduced annual survival
Robbins et al. 1989, Rappole \& McDonald 1994, Haney et al. 1998

Bohning-Gaese et al. 1993, Latta \& Baltz 1997

Norris et al. 2004b, Drent et al. 2006

Baker et al. 2004

Pettifor et al. 2000

Gauthier et al. 2005

Ratner et al. 1997, Kareiva et al. 2000, Wilson 2003

Fraser et al. 2007

Bolger et al. 2008

Berger 2004, Thirgood et al. 2004 butterflies

waterfowl

birds (various)

salmonids

seabirds, sea turtles
Vandenbosch 2003

Lehikoinen et al. 2006, Kéry et al. 2006

Newton 2007 (review)

Friedland et al. 1993, Bisbal \& McConnaha 1998

Lee et al. 2007, Saba et al. 2007

ungulates

Owen-Smith et al. 2005 
Decline in climate-linked food sources

Variable seasonal rates of change reduced reproductive success

mistimed breeding phenology birds (general)

shorebirds; passerines
Bairlein \& Huppop 2004, Ward et al. 2005, Lee et al. 2007

Stenseth \& Mysterud 2002, Drent et al. 2003, Both et al. 2006

\section{MORTALITY/DISTURBANCE}

Sport harvest

Declining sport harvest

Disturbance at staging sites

Ship collision/gear entanglement

Fisheries bycatch reduced nonbreeding survival

increased survival

reduced pre-breeding condition

reduced nonbreeding survival

reduced nonbreeding survival waterfowl; salmonids

waterfowl

waterfowl

marine mammals

marine reptiles; seabirds
Menu et al. 2002, Calvert \& Gauthier 2005, Quinn 2005

Gauthier et al. 2005

Mainguy et al. 2002, Klaassen et al. 2006

Caswell et al. 1999, Runge et al. 2004, Kraus et al. 2005

Crowder et al. 1994, Cuthbert et al. 2001, James et al. 2005, Phillips et al. 2005

\section{Recommendations}

The use of many dispersed habitats by long distance migrants presents logistical constraints to the comprehensive estimation of seasonal vital rates. Migrants are typically stationary when breeding, allowing for relatively accurate estimates of breeding parameters, whereas in nonbreeding seasons they travel vast distances across harsh or inaccessible environments (Alerstam et al. 2003). Many seasonal migrants, especially birds, also breed in high-latitude areas, corresponding with generally greater economic prosperity and better research funding. Nonbreeding-based conservation is often further limited by management jurisdictions. Canada's Species at Risk Act, for example, prohibits destruction of listed species' "critical habitat", but only within Canadian boundaries, whereas in other regions the geographical range of migrants extends well beyond the limits of protected areas (e.g., Thirgood et al. 2004). Nonetheless, with modern tools permitting individual tracking and temporal hindsight into the life cycles of diverse migrant taxa (Table 1), the necessary shift in conservation ideology toward a comprehensive cross-seasonal perspective can be realized via three principal actions:
Conservation plans must move away from the breeding-centric. Nonbreeding season parameters are not the only drivers of demography, and thus it is clearly important to continue efforts to maintain or increase survivorship and reproduction of migrants during the breeding season in situations where population regulation depends largely on events during reproduction. However, more explicit recognition of the connections between seasons is required to guide allocation of resources effectively (Martin et al. 2007). Habitat alteration, climatic change, and direct mortality during nonbreeding seasons have important consequences for diverse migratory taxa (Table 3). In salmonid fishes, recovery efforts must extend beyond spawning streams (e.g., Kareiva et al. 2000, Wilson 2003) to address ocean-phase mortality and near-shore habitats (Bisbal and McConnaha 1998, Greene and Beechie 2004). Protection of stopover areas, including a better understanding of the scales at which these sites should be viewed (Buler et al. 2007), should be integral to songbird conservation (Moore et al. 1995, Hutto 2000), and monitoring of songbird winter habitat may reveal the causes of some population declines (Dit Durell et al. 1997, Holmes 2007). A cross-seasonal perspective is most urgently required for endangered populations, where identification of nonbreeding habitat is critical to recovery, e.g., for leatherback sea turtle 
Dermochelys coriacea (James et al. 2005, SherrillMix et al. 2008), and where damage to these habitats may be ignored under breeding-focused conservation efforts, e.g., for Kirtland's Warbler Dendroica kirtlandii (Haney et al. 1998). When nonbreeding information is still lacking, knowledge gained from studies of other migrants may provide valuable insight into demographic patterns or conservation needs common to diverse migratory taxa (see Martin et al. 2007, Bolger et al. 2008, Robinson et al. 2008, Sherrill-Mix et al. 2008).

Season-specific vital rates, their relative contributions to population growth, and the withinpopulation variation in these parameters must be better quantified. The impact of threats to nonbreeding survival relative to factors influencing survival and breeding success on the breeding grounds must be measured before we can identify the most critical habitats or most vulnerable age classes (e.g., Crowder et al. 1994, Mduma et al. 1999, Owen-Smith et al. 2005). Current sensitivity estimates support the key role of nonbreeding vital rates in the population dynamics of most migratory species, but improved quantification of survival, dispersal and reproductive parameters and their sensitivities will enable conservation biologists to anticipate nonbreeding events that threaten the persistence of species already at risk (e.g., Baker et al. 2004). When possible, estimates of vital rates should also be sex-specific, as projections of population dynamics may be highly dependent upon recognition of sex differences in survival and reproduction (Ezard et al. 2006, Rankin and Kokko 2007).

Conservation of migrants must include the development of population growth models that incorporate seasonal components of migratory life cycles. A partitioning of mortality risks and reproductive influences among all seasonal habitats, as well as an improved understanding of how those seasonal parameters interact, will allow conservation goals and management actions to be specifically tailored to particular seasons or life stages (e.g., Baker et al. 2004, Calvert and Gauthier 2005). Through assessment of both sensitivity and variability in vital rates, projection models will permit the identification of the optimal targets for conservation, and taxonomic parallels mean that model development for poorly-known taxa can build upon demographic characteristics of other migrants (Martin et al. 2007, Bolger et al. 2008).
Manipulation of highly-sensitive parameters might not always represent the best investment of resources (Mills et al. 1999, Hoekman et al. 2006): if nonbreeding survival is near the maximal rate possible or otherwise invariable, efforts aimed at increasing survival during this period might yield only minor changes to population growth and more flexible vital rates will be better conservation targets (Gaillard et al. 2000, Wemmer et al. 2001). Where seasonal data are sparse, population models could incorporate incomplete data or information from other similar migrants using methods that account for error and uncertainty (e.g., Besbeas et al. 2002, Hoyle and Maunder 2004). The inclusion of partial data, vital rate approximations, or data from other populations into projection models may fill critical gaps remaining in our understanding of seasonal migrants' complex population dynamics.

\section{CONCLUSION}

Some recent studies have effectively quantified nonbreeding influences in passerines (e.g., Runge and Marra 2005, Webster and Marra 2005). Others have established their significance across broader avian taxa (Newton 2004, 2006). Nevertheless, the heuristic value of this work to seasonal migrants as a whole, where nonbreeding effects demonstrated in birds may be equally critical to the dynamics of other migratory populations, has not yet been fully exploited (Bolger et al. 2008, Robinson et al. 2008). Our review highlights the need for a shift in migration research away from a single-season focus and toward explicit recognition of the complexity of migratory demography. At a minimum, this requires a multi-taxa and multi-seasonal perspective that encompasses the entire life cycle, including clearer recognition of how seasonal vital rates contribute to population growth and how they interact across temporal and spatial scales. Such an approach will require a more focused and standardized quantification of seasonal vital rates, and further development of population models that account for these interactions: attention to these details will enable a more preventative approach to conservation planning that projects future impacts of climatic and anthropogenic change. Only with such insight can we decipher the links between environment and demography necessary to the conservation of migratory populations. 
Responses to this article can be read online at: http://www.ace-eco.org/vol4/iss2/art5/responses/

\section{Acknowledgments:}

Funding for this study was provided by the Atlantic Cooperative Wildlife Ecology Research Network (ACWERN), a Natural Sciences and Engineering Research Council (NSERC) Discovery Grant to PDT, and a Canada Graduate Scholarship (NSERC) and Killam Trusts Scholarship to AMC. Thank you to Caroline Calvert, Dylan Fraser, Andy Horn, Marty Leonard, Greg Robertson, and two anonymous reviewers for discussions and comments that greatly improved previous drafts of the manuscript.

\section{LITERATURE CITED}

Adahl, E., P. Lundberg, and N. Jonzén. 2006. From climate change to population change: the need to consider annual life cycles. Global Change Biology 12:1627-1633.

Alerstam, T., A. Hedenstrom, and S. Akesson. 2003. Long-distance migration: evolution and determinants. Oikos 103:247-260.

Alerstam, T., and P. H. Enckell. 1979. Unpredictable habitats and evolution of bird migration. Oikos 33:228-232.

Alisauskas, R. T. 2002. Arctic climate, spring nutrition, and recruitment in midcontinent lesser snow geese. Journal of Wildlife Management 66:181-193.

Anders, A. D., D. C. Dearborn, J. Faaborg, and F. R. I. Thompson. 1997. Juvenile survival in a population of neotropical migrant birds. Conservation Biology 11:698-707.

Austin, G. E., and M. M. Rehfisch. 2005. Shifting nonbreeding distributions of migratory fauna in relation to climate change. Global Change Biology 11:31-38.

Bairlein, F., and O. Huppop. 2004. Migratory fuelling and global climate change. Advances in Ecological Research 35:33-47.
Baker, A. J., P. M. Gonzales, T. Piersma, L. J. Niles, I. L. S. de Nascimento, P. W. Atkinson, N. A. Clark, C. D. T. Minton, M. K. Peck, and G. Aarts. 2004. Rapid population decline in red knots: fitness consequences of decreased refuelling rates and later arrival in Delaware Bay. Proceedings of the Royal Society B 271:875-882.

Baldaccini, N.E., and E.M. Bezzi. 1989. Orientational responses to different light stimuli by adult and young Sedge Warblers (Acrocephalus schoenobaenus) during autumn migration: a funnel technique study. Behaviour 110:115-124.

Beacham, T. D., J. R. Candy, B. McIntosh, C. MacConnachie, A. Tabata, K. Kaukinen, L. Deng, K. M. Miller, and R. E. Withler. 2005. Estimation of stock composition and individual identification of sockeye salmon on a Pacific Rim basis using microsatellite and major histocompatibility complex variation. Transactions of the American Fisheries Society 134:1124-1146.

Beamish, R. J., C. Mahnken, and C. M. Neville. 2004. Evidence that reduced early marine growth is associated with lower marine survival of coho salmon. Transactions of the American Fisheries Society 133:26-33.

Bearhop, S., G. M. Hilton, S. C. Votier, and S. Waldron. 2004. Stable isotope ratios indicate that body condition in migrating passerines is influenced by winter habitat. Proceedings of the Royal Society B 271:S215-S218.

Beissinger, S. R., and M. I. Westphal. 1998. On the use of demographic models of population viability in endangered species management. Journal of Wildlife Management 62:821-841.

Berger, J. 2004. The last mile: how to sustain longdistance migration in mammals. Conservation Biology 18:320-331.

Bergerud, A. T., and J. P. Elliot. 1986. Dynamics of caribou and wolves in northern British Columbia. Canadian Journal of Zoology 64:1515-1529.

Berthold, P., A. J. Helbig, G. Mohr, and U. Querner. 1992. Rapid microevolution of migratory behaviour in a wild bird species. Nature 360:668-690.

Berthold, P., and F. Pulido. 1994. Heritability of 
migratory activity in a natural bird population. Proceedings of the Royal Society B 257:311-315.

Besbeas, P., S. N. Freeman, B. J. T. Morgan, and E. A. Catchpole. 2002. Integrating markrecapture-recovery and census data to estimate animal abundance and demographic parameters. Biometrics 58:540-547.

Bêty, J., J.-F. Giroux, and G. Gauthier. 2004. Individual variation in timing of migration: causes and reproductive consequences in greater snow geese (Anser caerulescens atlanticus). Behavioural Ecology and Sociobiology 57:1-8.

Bisbal, G. A., and W. E. McConnaha. 1998. Consideration of ocean conditions in the management of salmon. Canadian Journal of Fisheries and Aquatic Sciences 55:2178-2186.

Block, B. A., S. L. H. Teo, A. Walli, A. Boustany, M. J. W. Stokesbury, C. J. Farwell, K. C. Weng, H. Dewar, and T. D. Williams. 2005. Electronic tagging and population structure of Atlantic bluefin tuna. Nature 434:1121-1127.

Bohning-Gaese, K., M. L. Taper, and J. H. Brown. 1993. Are declines in North American insectivorous songbirds due to causes on the breeding range? Conservation Biology 7:76-86.

Bolger, D. T, W. D. Newmark, T. A. Morrison, and D. F. Doak. 2008. The need for integrative approaches to understand and conserve migratory ungulates. Ecology Letters 11:63-77.

Boone, R. B., S. J. Thirgood, and J. G. C. Hopcraft. 2006. Serengeti wildebeest migratory patterns modeled from rainfall and new vegetation growth. Ecology 87:1987-1994.

Both, C., R. G. Bijlsma, and M. E. Visser. 2005. Climatic effects on timing of spring migration and breeding in a long-distance migrant, the pied flycatcher Ficedula hypoleuca. Journal of Avian Biology 36:368-373.

Both, C., S. Bouwhuis, C. M. Lessells, and M. E. Visser. 2006. Climate change and population declines in a long-distance migratory bird. Nature 441:81-83.

Boulet, M., S. Couturier, S. D. Côté, R. D. Otto, and L. Bernatchez. 2007. Integrative use of spatial, genetic, and demographic analyses for investigating genetic connectivity between migratory, montane, and sedentary caribou herds. Molecular Ecology 16:4223-4240.

Brault, S., and H. Caswell. 1993. Pod-specific demography of killer whales (Orcinus orca). Ecology 74:1444-1454.

Buehler, D. M., and T. Piersma. 2008. Travelling on a budget: predictions and ecological evidence for bottlenecks in the annual cycle of long-distance migrants. Philosophical Transactions of the Royal Society B 363:247-266.

Buler, J. J., F. R. Moore, and S. Woltmann. 2007. A multi-scale examination of stopover habitat use by birds. Ecology 88:1789-1802.

Butler, R. W. 2000. Stormy seas for some North American songbirds: are declines related to severe storms during migration? Auk 117:518-522.

Calvert, A. M., D. L. Amirault, F. Shaffer, R. Elliot, A. Hanson, J. McKnight, and P. D. Taylor. 2006. Population assessment of an endangered shorebird: the piping plover (Charadrius melodus melodus) in eastern Canada. Avian Conservation and Ecology - Écologie et conservation des oiseaux 1:4. Available online at: http://www.ace-eco.org/vol1/ iss3/art4/.

Calvert, A. M., and G. Gauthier. 2005. Effects of exceptional conservation measures on survival and seasonal hunting mortality in greater snow geese. Journal of Applied Ecology 42:442-452.

Calvert, A. M., P. D. Taylor, and S. Walde. 2009. Cross-scale environmental influences on songbird stopover behaviour. Global Change Biology 15:744-759.

Campana, S. E., G. A. Chouinard, J. M. Hanson, and A. Fréchet. 1999. Mixing and migration of overwintering Atlantic cod (Gadus morhua) stocks near the mouth of the Gulf of St Lawrence. Canadian Journal of Fisheries and Aquatic Sciences 56:1873-1881.

Caswell, H. 2001. Matrix population models: construction, analysis and interpretation. Sinauer Associates Inc., Sunderland, Massachusetts, USA.

Caswell, H., M. Fujiwara, and S. Brault. 1999. Declining survival probability threatens the North Atlantic right whale. Proceedings of the National Academy of Sciences USA 96:3308-3313. 
Cilimburg, A. B., M. S. Lindberg, J. J. Tewksbury, and S. J. Hejl. 2002. Effects of dispersal on survival probability of adult yellow warblers (Dendroica petechia). Auk 119:778-789.

Clegg, S. M., J. F. Kelly, M. Kimura, and T. B. Smith. 2003. Combining genetic markers and stable isotopes to reveal population connectivity and migration patterns in a Neotropical migrant, Wilson's warbler (Wilsonia pusilla). Molecular Ecology 12:819-830.

Conroy, M. J., G. R. Costanzo, and D. B. Stotts. 1989. Winter survival of female American black ducks on the Atlantic coast. Journal of Wildlife Management 53:99-109.

Conway, C. J., G. V. N. Powell, and J. D. Nichols. 1995. Overwinter survival of Neotropical migratory birds in early-successional and mature tropical forests. Conservation Biology 9:855-864.

Corkeron, P. J., and R. C. Connor. 1999. Why do baleen whales migrate? Marine Mammal Science 15:1228-1245.

Cotton, P. A. 2003. Avian migration phenology and global climate change. Proceedings of the National Academy of Sciences USA 100:12219-12222.

Courtois, R., L. Bernatchez, J.-P. Ouellet, and L. Breton. 2003. Significance of caribou (Rangifer tarandus) ecotypes from a molecular genetics viewpoint. Conservation Genetics 4:393-404.

Cox, G. W. 1968. The role of competition in the evolution of migration. Evolution 22:180-192.

Cox, G. W. 1985. The evolution of avian migration systems between temperate and tropical regions of the New World. American Naturalist 126:451-474.

Crowder, L. B., D. T. Crouse, S. S. Heppell, and T. H. Martin. 1994. Predicting the impact of turtle excluder devices on loggerhead sea turtle populations. Ecological Applications 4:437-445.

Cuthbert, R., D. Fletcher, and L. S. Davis. 2001. A sensitivity analysis of Hutton's shearwater: prioritizing conservation research and management. Biological Conservation 100:163-172.

Dingle, H. 1996. Migration: The Biology of Life on the Move. Oxford University Press, New York, New York, USA.
Dingle, H. 2006. Animal migration: is there a common migratory syndrome? Journal of Ornithology 147:212-220.

Dit Durell, S. E. A. L. V., J. D. Goss-Custard, and R. T. Clarke. 1997. Differential response of migratory subpopulations to winter habitat loss. Journal of Applied Ecology 34:1155-1164.

Doak, D. F., W. F. Morris, C. Pfister, B. E. Kendall, and E. M. Bruna. 2005. Correctly estimating how environmental stochasticity influences fitness and population growth. American Naturalist 166:E14-E21.

Dolman, P. M., and W. J. Sutherland. 1994. The response of bird populations to habitat loss. Ibis 137: S38-S46.

Drent, R. H., A. D. Fox, and J. Stahl. 2006. Travelling to breed. Journal of Ornithology 147:122-134.

Drent, R., C. Both, M. Green, J. Madsen, and T. Piersma. 2003. Pay-offs and penalties of competing migratory schedules. Oikos 103:274-292.

Esler, D. 2000. Applying metapopulation theory to conservation of migratory birds. Conservation Biology 14:366-372.

Ezard, T. H. G., P. H. Becker, and T. Coulson. 2006. The contributions of age and sex to variation in common tern population growth rate. Journal of Animal Ecology 75:1379-1386.

Fancy, S. G., K. R. Whitten, and D. E. Russell. 1994. Demography of the Porcupine caribou herd, 1983-1992. Canadian Journal of Zoology 72:840-846.

Ferguson, S. H., and P. C. Elkie. 2004. Seasonal movement patterns of woodland caribou (Rangifer tarandus caribou). Journal of Zoology 262:125134.

Firestone, J., S. B. Lyons, C. Wang, and J. J. Corbett. 2008. Statistical modeling of North Atlantic right whale migration along the midAtlantic region of the eastern seaboard of the United States. Biological Conservation 141:221-232.

Fletcher, R. J. Jr., R. R. Koford, and D. A. Seaman. 2006. Critical demographic parameters 
for declining songbirds breeding in restored grasslands. Journal of Wildlife Management 70:145-157.

Fox, A. D., C. M. Glahder, and A. J. Walsh. 2003. Spring migration routes and timing of Greenland white-fronted geese-results from satellite telemetry. Oikos 103:415-425.

Francis, C. M., M. H. Richards, F. Cooke, and R. F. Rockwell. 1992. Changes in survival rates of lesser snow geese with age and breeding status. Auk 109:731-747.

Fraser, D. J., and L. Bernatchez. 2005. Adaptive migratory divergence among sympatric brook charr populations. Evolution 59:611-624.

Fraser, D. J., P. Duchesne, and L. Bernatchez. 2005. Migratory charr schools exhibit population and kin associations beyond juvenile stages. Molecular Ecology 14:3133-3146.

Fraser, D. J., M. W. Jones, T. L. McParland, and J. A. Hutchings. 2007. Loss of historical immigration and the unsuccessful rehabilitation of extirpated salmon populations. Conservation Genetics 8:527-546.

Frederiksen, M., M. P. Harris, and S. Wanless. 2005. Inter-population variation in demographic parameters: a neglected subject? Oikos 111:209-214.

Fretwell, S. D. 1972. Populations in a Seasonal Environment. Princeton University Press, Princeton, New Jersey, USA.

Friedland, K. D. 1998. Ocean climate influences on critical Atlantic salmon (Salmo salar) life history events. Canadian Journal of Fisheries and Aquatic Sciences 55 (supplement 1):119-130.

Friedland, K. D., G. Chaput, and J. C. MacLean. 2005. The emerging role of climate in post-smolt growth of Atlantic salmon. ICES Journal of Marine Science 62:1338-1349.

Friedland, K. D., D. G. Reddin, and J. F. Kocik. 1993. Marine survival of North American and European Atlantic salmon: effects of growth and environment. ICES Journal of Marine Science 50:481-492.
Fryxell, J.M. 1987. Food limitation and demography of a migratory antelope, the whiteeared kob. Oecologia 72:83-91.

Fujiwara, M., and H. Caswell. 2001. Demography of the endangered North Atlantic right whale. Nature 414:537-541.

Gaillard, J. M., M. Festa-Bianchet, N. G. Yoccoz, A. Loison, and C. Toigo. 2000. Temporal variation in fitness components and population dynamics of large herbivores. Annual Reviews in Ecology and Systematics 31:367-393.

Gauthier, G., J.-F. Giroux, A. Reed, A. Béchet, and L. Belanger. 2005. Interactions between land use, habitat use and population increase in greater snow geese: what are the consequences for natural wetlands? Global Change Biology 11:856-868.

Gauthier, G., R. Pradel, S. Menu, and J.-D. Lebreton. 2001. Seasonal survival of greater snow geese and effect of hunting under dependence in sighting probability. Ecology 82:3105-3119.

Gauthreaux, S. A., J. E. Michi, and C. G. Belser. 2005. The temporal and spatial structure of the atmosphere and its influence on bird migration strategies. Pages 182-193 in R. Greenberg and P.P. Marra, editors. Birds of Two Worlds. Johns Hopkins University Press, Baltimore, Maryland, USA.

Greene, C. M., and T. J. Beechie. 2004. Consequences of potential density-dependent mechanisms on recovery of ocean-type chinook salmon (Oncorhynchus tshawytscha). Canadian Journal of Fisheries and Aquatic Sciences 61:590-602.

Grosbois, V., and P. M. Thompson. 2005. North Atlantic climate variation influences survival in adult fulmars. Oikos 109:273-290.

Gunnarsson, T. G., J. A. Gill, P. W. Atkinson, G. Gélinaud, P. M. Potts, R. E. Croger, G. A. Gudmundsson, G. F. Appleton, and W. J. Sutherland. 2006. Population-scale drivers of individual arrival times in migratory birds. Journal of Animal Ecology 75:1119-1127.

Gunnarsson, T. G., J. A. Gill, J. Newton, P. M. Potts, and W. J. Sutherland. 2005. Seasonal matching of habitat quality and fitness in a 
migratory bird. Proceedings of the Royal Society of London Series B 272:2319-2323.

Haney, J. C., D. S. Lee, M. Walsh-McGehee. 1998. A quantitative analysis of winter distribution and habitats of Kirtland's warblers in the Bahamas. Condor 100:201-217.

Hansen, L. P., and T. P. Quinn. 1998. The marine phase of the Atlantic salmon (Salmo salar) life cycle, with comparisons to Pacific salmon. Canadian Journal of Fisheries and Aquatic Sciences 55 (supplement 1):104-118.

Harewood, A., and J. Horrocks. 2008. Impacts of coastal development on hawksbill hatchling survival and swimming success during the initial offshore migration. Biological Conservation 14:394-401.

Hebblewhite, M., and E. H. Merrill. 2007. Multiscale wolf predation risk for elk: does migration reduce risk? Oecologia 152:377-387.

Heppell, S. S., H. Caswell, and L. B. Crowder. 2000. Life histories and elasticity patterns: perturbation analysis for species with minimal demographic data. Ecology 81:654-665.

Hitchcock, C. L., and C. Gratto-Trevor. 1997. Diagnosing a shorebird local population decline with a stage-structured population model. Ecology 78:522-534.

Hobson, K. A. 2005. Flying fingerprints: making connections with stable isotopes and trace elements. Pages 235-246 in R. Greenberg and P.P. Marra, editors. Birds of Two Worlds. Johns Hopkins University Press, Baltimore, Maryland, USA.

Hoekman, S. T., T. S. Gabor, M. J. Petrie, R. Maher, H. R. Murkin, and M. S. Lindberg. 2006. Population dynamics of mallards breeding in agricultural environments in eastern Canada. Journal of Wildlife Management 70:121-128.

Holmes, R. T. 2007. Understanding population change in migratory songbirds: long-term and experimental studies of Neotropical migrants in breeding and wintering areas. Ibis 149 (supplement 2):2-13.

Holmes, R. T., T. W. Sherry, and L. Reitsma. 1989. Population structure, territoriality and overwinter survival of two migrant warbler species in Jamaica. Condor 91:545-561.

Holtby, L. B., and M. C. Healey. 1990. Sexspecific life history tactics and risk-taking in coho salmon. Ecology 71:678-690.

Hoyle, S. D., and M. N. Maunder. 2004. A Bayesian integrated population dynamics model to analyze data for protected species. Animal Biodiversity and Conservation 27:247-266.

Hunter, E., J. D. Metcalfe, G. P. Arnold, and J. D. Reynolds. 2004. Impacts of migratory behaviour on population structure in North Sea plaice. Journal of Animal Ecology 73:377-385.

Hutto, R. L. 2000. On the importance of en route periods to the conservation of migratory landbirds. Studies in Avian Biology 20:109-114.

Intergovernmental Panel on Climate Change (IPCC). 2007. Climate Change 2007: Synthesis Report. Contribution of Working Groups I, II and III to the Fourth Assessment Report of the Intergovernmental Panel on Climate Change [Core Writing Team, R. K. Pachauri and A. Reisinger (eds.)]. IPCC, Geneva, Switzerland.

James, M. C., C. A. Ottensmeyer, and R. A. Myers. 2005. Identification of high-use habitat and threats to leatherback sea turtles in northern waters: new directions for conservation. Ecology Letters 8:195-201.

Jones, J., J. J. Barg, T. S. Sillett, M. L. Veit, and R. J. Robertson. 2004. Minimum estimates of survival and population growth for cerulean warblers (Dendroica cerulea) breeding in Ontario, Canada. Auk 121:15-22.

Kareiva, P., M. Marvier, and M. McClure. 2000. Recovery and management options for spring/ summer chinook salmon in the Columbia River basin. Science 290:977-979.

Kéry, M., J. Madsen, and J. D. Lebreton. 2006. Survival of Svalbard pink-footed geese Anser brachyrhynchus in relation to winter climate, density and land-use. Journal of Animal Ecology 75:172-1181.

Ketterson, E. D., and V. Nolan Jr. 1982. The role of migration and winter mortality in the life history 
of a temperate-zone migrant, the dark-eyed junco, as determined from demographic analyses of winter populations. Auk 99:243-259.

Klaassen, M., S. Bauer, J. Madsen, and I. Tombre. 2006. Modelling behavioural and fitness consequences of disturbance for geese along their spring flyway. Journal of Applied Ecology 43:92-100.

Kokko, H. 1999. Competition for early arrival in migratory birds. Journal of Animal Ecology 68:940-950.

Kokko, H., T. G. Gunnarsson, L. J. Morrell, and J. A. Gill. 2006. Why do female migratory birds arrive later than males? Journal of Animal Ecology 75:1379-1386.

Kraus, S. D., M. W. Brown, H. Caswell, C. W. Clark, M. Fujiwara, P. K. Hamilton, R. D. Kenney, A. R. Knowlton, S. Landry, C. A. Mayo, W. A. McLellan, M. J. Moore, D. P. Nowacek, D. A. Pabst, A. J. Read, and R. M. Rolland. 2005. North Atlantic right whales in crisis. Science 309:561-562.

Laaksonen, T., M. Ahola, T. Eeva, R. A. Vaisanen, and E. Lehikoinen. 2006. Climate change, migratory connectivity and changes in laying date and clutch size of the pied flycatcher. Oikos 114:277-290.

Lack, D. 1968. Bird migration and natural selection. Oikos 19:1-9.

Latta, S. C., and M. E. Baltz. 1997. Population limitation in neotropical migratory birds: comments on Rappole and McDonald (1994). Auk 114:754-762.

Lee, D. E., N. Nur, and W. J. Sydeman. 2007. Climate and demography of the planktivorous Cassin's auklet Ptychoramphys aleuticus off northern California: implications for population change. Journal of Animal Ecology 76:337-347.

Lehikoinen, A., M. Kilpi, and M. Öst. 2006. Winter climate affects subsequent breeding success of common eiders. Global Change Biology 12:1355-1365.

Lemoine, N., and K. Bohning-Gaese. 2003. Potential impact of global climate change on species richness of long-distance migrants. Conservation Biology 17:577-586.

Lopes, R. J., J. C. Marques, and L. Wennerberg. 2006. Migratory connectivity and temporal segregation of dunlin (Calidris alpina) in Portugal: evidence from morphology, ringing recoveries and mtDNA. Journal of Ornithology 147:385-394.

Madsen, J., M. Frederiksen, and B. Ganter. 2002. Trends in annual and seasonal survival of pinkfooted geese Anser brachyrhynchus. Ibis 144:218-226.

Mainguy, J., J. Bêty, G. Gauthier, and J.-F. Giroux. 2002. Are body condition and reproductive effort of laying greater snow geese affected by the spring hunt? Condor 104:156-161.

Marra, P. P., and R. L. Holberton. 1998. Corticosterone levels as indicators of habitat quality: effects of habitat segregation in a migratory bird during the non-breeding season. Oecologia 116: $284-292$.

Marra, P. P., and R. T. Holmes. 2001. Consequences of dominance-mediated habitat segregation in American redstarts during the nonbreeding season. Auk 118:92-104.

Martin, T. G., I. Chadès, P. Arcese, P. P. Marra, H. P. Possingham, and D. R. Norris. 2007. Optimal conservation of migratory species. Public Library of Science ONE 2:e751.

McNamara, J.M, and A.I. Houston. 2008. Optimal annual routines: behaviour in the context of physiology and ecology. Philosophical Transactions of the Royal Society of London B 363: 301-319.

Mduma, S. A. R., A. R. E. Sinclair, and R. Hilborn. 1999. Food regulates the Serengeti wildebeest: a 40-year record. Journal of Animal Ecology 68:1101-1122.

Mehlman, D. W., S. E. Mabey, D. N. Ewert, C. Duncan, B. Abel, D. Cimprich, R. D. Sutter, and M. Woodrey. 2005. Conserving stopover sites for forest-dwelling migratory landbirds. Auk 122:1281-1290.

Menu, S., G. Gauthier, and A. Reed. 2002. Changes in survival rates and population dynamics of greater snow geese over a 30-year period: 
implications for hunting regulations. Journal of Applied Ecology 39:91-102.

Menu, S., G. Gauthier, and A. Reed. 2005. Survival of young greater snow geese (Chen caerulescens atlantica) during fall migration. Auk 122:479-496.

Mills, L. S., D. F. Doak, and M. J. Wisdom. 1999. Reliability of conservation actions based on elasticity analysis of matrix models. Conservation Biology 13:815-829.

Möller, A. P. 1989. Population dynamics of a declining swallow Hirundo rustica population. Journal of Animal Ecology 58:1051-1063.

Moore, F. R., R. J. Smith, and R. Sandberg, R. 2005. Stopover ecology of intercontinental migrants: en route problems and consequences for reproductive performance. Pages 251-261 in: $\mathrm{R}$. Greenberg and P.P. Marra, editors. Birds of Two Worlds. Johns Hopkins University Press, Baltimore, Maryland, USA.

Moore, F. R., S. A. Gauthreaux, P. Kerlinger, and T. R. Simons. 1995. Habitat requirements during migration: important link in conservation. Pages 121-144 in T.E. Martin and D.M. Finch, editors. Ecology and Management of Neotropical Migratory Birds. Oxford University Press, New York, New York, USA.

Newton, I. 2004. Population limitation in migrants. Ibis 146:197-226.

Newton, I. 2006. Can conditions experienced during migration limit the population levels of birds? Journal of Ornithology 147:146-166.

Newton, I. 2007. Weather-related mass-mortality events in migrants. Ibis 149:453-467

Norris, D. R. 2005. Carry-over effects and habitat quality in migratory populations. Oikos 109:178-186.

Norris, D. R., P. P. Marra, T. K. Kyser, T. W. Sherry, and L. M. Ratcliffe. 2004a. Tropical winter habitat limits reproductive success on the temperate breeding grounds in a migratory bird. Proceedings of the Royal Society B 271:59-64.

Norris, K., P. W. Atkinson, and J. A. Gill. $2004 b$. Climate change and coastal waterbird populations
- past declines and future impacts. Ibis 146 (supplement1):82-89.

Oberhauser, K., and A. T. Peterson. 2003. Modeling current and future potential wintering distributions of eastern North American monarch butterflies. Proceedings of the National Academy of Sciences USA 100:14063-14068.

Owen-Smith, N., D. R. Mason, and J. O. Ogutu. 2005. Correlates of survival rates for 10 African ungulate populations: density, rainfall and predation. Journal of Animal Ecology 74:774-788.

Pascual, M., P. Bentzen, C. R. Rossi, G. Mackey, M. T. Kinnison, and R. Walker. 2001. First documented case of anadromy in a population of introduced rainbow trout in Patagonia, Argentina. Transactions of the American Fisheries Society 130:53-67.

Perez-Tris, J., and J. L. Telleria. 2002. Migratory and sedentary blackcaps in sympatric non-breeding grounds: implications for the evolution of avian migration. Journal of Animal Ecology 71:211-224.

Pettifor, R. A., R. W. G. Caldow, J. M. Rowcliffe, J. D. Goss-Custard, J. M. Black, K. H. Hodder, A. I. Houston, A. Lang, and J. Webb. 2000. Spatially explicit, individual-based, behavioural models of the annual cycle of two migratory goose populations. Journal of Applied Ecology 37 (supplement 1):103-135.

Pfister, C. A. 1998. Patterns of variance in stagestructured populations: evolutionary predictions and ecological implications. Proceedings of the National Academy of Sciences USA 95:213-218.

Phillips, R. A., J. R. D. Silk, J. P. Croxall, V. Afanasyev, and V. J. Bennett. 2005. Summer distribution and migration of nonbreeding albatrosses: individual consistencies and implications for conservation. Ecology 86:2386-2396.

Pienkowski, M. W., and P. R. Evans. 1984. The role of migration in the population dynamics of birds. Pages 331-351 in R. M. Sibly and R. H. Smith, editors. Behavioural Ecology: Ecological Consequences of Adaptive Behaviour. Blackwell Scientific Publications, Oxford, UK.

Pradel, R. 2005. Program E-SURGE: A software application for fitting multievent models. 
Biometrics 61:442-447.

Quinn, T. P. 2005. The Behaviour and Ecology of Pacific Salmon and Trout. University of Washington Press, Seattle, Washington, USA.

Quinn, T. P. and K. W. Myers. 2004. Anadromy and the marine migrations of Pacific salmon and trout: Rounsefell revisited. Reviews in Fish Biology and Fisheries 14:421-442.

Rankin, D. J., and H. Kokko. 2007. Do males matter? The role of males in population dynamics. Oikos 116:335-348.

Rappole, J. H. and M. V. McDonald. 1994. Cause and effect in population declines of migratory birds. Auk 111:652-660.

Ratner, S., R. Lande, and B. B. Roper. 1997. Population viability analysis of spring chinook salmon in the South Umpqua River, Oregon. Conservation Biology 11:879-889.

Raveling, D. G., J. D. Nichols, J. E. Hines, D. S. Zezulak, J. G. Silveira, J. C. Johnson, T. W. Aldrich, and J. A. Weldon. 1992. Survival of cackling Canada geese, 1982-1988. Journal of Wildlife Management 56:63-73.

Reed, E. T., G. Gauthier, and J.-F. Giroux. 2004. Effects of spring conditions on breeding propensity of greater snow goose females. Animal Biodiversity and Conservation 27:35-46.

Robbins, C. S., J. R. Sauer, R. S. Greenberg, and S. Droege. 1989. Population declines in North American birds that migrate to the neotropics. Proceedings of the National Academy of Sciences 86:7658-7662.

Robertson, G. J., and F. Cooke. 1999. Winter philopatry in migratory waterfowl. Auk 116:20-34.

Robinson, R.A., H. Q. P. Crick, J. A. Learmonth, I. M. D. Maclean, C. D. Thomas, F. Bairlein, M. C. Forchhammer, C. M. Francis, J. A. Gill, B. J. Godley, J. Harwood, G. C. Hays, B. Huntley, A. M. Hutson, G. J. Pierce, M. M. Rehfisch, D. W. Sims, M. Begoña Santos, T. H. Sparks, D. A. Stroud, M. E. Visser. 2008. Traveling through a warming world: climate change and migratory species. Endangered Species Research Available online at: http://www.int-res.com/articles/esr2008/theme/ ICC/ICCpp2.pdf.

Ruggerone, G. T., M. Zimmermann, K. W. Myers, J. L. Nielsen, and D. E. Rogers. 2003. Competition between Asian pink salmon (Oncorhynchus gorbuscha) and Alaskan sockeye salmon $(O$. nerka) in the North Pacific Ocean. Fisheries and Oceanography 12:209-219.

Runge, M. C., C. A. Langtimm, and W. L. Kendall. 2004. A stage-based model of manatee population dynamics. Marine Mammal Science 20:361-385.

Runge, M. C., and P. P. Marra. 2005. Modeling seasonal interactions in the population dynamics of migratory birds. Pages 275-389 in R. Greenberg and P. P. Marra, editors. Birds of Two Worlds. Johns Hopkins University Press, Baltimore, Maryland, USA.

Saba, V. S., P. Santidrián-Tomillo, R. D. Reina, J. R. Spotila, J. A. Musick, D. E. Evans, and F. V. Paladino. 2007. The effect of the El Niño Southern Oscillation on the reproductive frequency of eastern Pacific leatherback turtles. Journal of Applied Ecology 44:395-404.

Saether, B.-E., and O. Bakke. 2000. Avian life history variation and contribution of demographic traits to the population growth rate. Ecology 81:642-653.

Saether, B.-E., T. H. Ringsby, and E. Roskaft. 1996. Life history variation, population processes and priorities in species conservation: towards a reunion of research paradigms. Oikos 77:217-226.

Saino, N., T. Szep, M. Romano, D. Rubolini, F. Spina, and A. P. Möller. 2004. Ecological conditions during winter predict arrival date at the breeding quarters in a trans-Saharan migratory bird. Ecology Letters 7:21-25.

Schaub, M., W. Kania, and U. Koppen. 2005. Variation in primary production during winter induces synchrony in survival rates in migratory white storks Ciconia ciconia. Journal of Animal Ecology 74:656-666.

Schaub, M., F. Liechti, and L. Jenni. 2004. Departure of migrating European robins, Erithacus 
rubecula, from a stopover site in relation to wind and rain. Animal Behaviour 67:229-237.

Schmutz, J. A., and C. R. Ely. 1999. Survival of greater white-fronted geese: effects of year, season, sex, and body condition. Journal of Wildlife Management 63:1239-1249.

Sherrill-Mix, S. A., M. C. James, and R. A. Myers. 2008. Migration cues and timing in leatherback sea turtles. Behavioral Ecology 19:231-236.

Sherry, T. W., and R. T. Holmes. 1996. Winter habitat quality, population limitation, and conservation of Neotropical-Nearctic migrant birds. Ecology 77:36-48.

Sherry, T. W., M. D. Johnson, and A. M. Strong. 2005. Does winter food limit populations of migratory birds? Pages 414-425 in R. Greenberg and P.P. Marra, editors. Birds of Two Worlds. Johns Hopkins University Press, Baltimore, Maryland, USA.

Sillett, T. S., and R. T. Holmes. 2002. Variation in survivorship of a migratory songbird throughout its annual cycle. Journal of Animal Ecology 71:296-308

Sillett, T. S., and R. T. Holmes. 2005. Long-term demographic trends, limiting factors, and the strength of density dependence in a breeding population of a migratory songbird. Pages 426-436 in R. Greenberg and P.P. Marra, editors. Birds of Two Worlds. Johns Hopkins University Press, Baltimore, Maryland, USA.

Sillett, T. S., R. T. Holmes, and T. W. Sherry. 2000. Impacts of a global climate cycle on population dynamics of a migratory songbird. Science 288:2040-2042.

Sims, D. W., V. J. Wearmouth, M. J. Genner, A. J. Southward, and S. J. Hawkins. 2004. Lowtemperature-driven early spawning migration of a temperate marine fish. Journal of Animal Ecology 73:333-341.

Skagan, S. K. 2006. Migration stopovers and the conservation of Arctic-breeding Calidrine sandpipers. Auk 123:313-322.

Spidle, A. P., T. P. Quinn, and P. Bentzen. 1998. Sex-biased marine survival and growth in a population of coho salmon. Journal of Fish Biology 52:907-915.

Stenseth, N. C., and A. Mysterud. 2002. Climate, changing phenology, and other life history traits: nonlinearity and match-mismatch to the environment. Proceedings of the National Academy of Science 99:13379-13381.

Stenseth, N. C., and A. Mysterud. 2005. Weather packages: finding the right scale and composition of climate in ecology. Journal of Animal Ecology 74:1195-1198.

Stutchbury, B.J.M., S.A. Tarof, T. Done, E. Gow, P.M. Kramer, J. Tautin, J.W. Fox, and V. Afanasyev. 2009. Tracking long-distance songbird migration by using geolocators. Science 323:896.

Sutherland, W.J. 1998. Evidence for flexibility and constraint in migration systems. Journal of Avian Biology 29:441-446.

Szep, T., and A. P. Möller. 2005. Using remote sensing data to identify migration and wintering areas and to analyze effects of environmental conditions on migratory birds. Pages 390-400 in R. Greenberg and P. P. Marra, editors. Birds of Two Worlds. Johns Hopkins University Press, Baltimore, Maryland, USA.

Tankersley, R. Jr., and K. Orvis. 2003. Modeling the geography of migratory pathways and stopover habitats for neotropical migratory birds. Conservation Ecology 7, 7. Available online at: http://www.cons ecol.org/vol7/iss1/art7

Thirgood, S., A. Mosser, S. Tham, G. Hopcraft, E. Mwangomo, T. Mlengeya, M. Kilewo, J. Fryxell, A. R. E. Sinclair, and M. Borner. 2004. Can parks protect migratory ungulates? The case of the Serengeti wildebeest. Animal Conservation 7:113-120.

Thompson, W. F. 1959. An approach to population dynamics of the Pacific red salmon. Transactions of the American Fisheries Society 88:206-209.

van der Jeugd, H. P., and K. Larsson. 1998. Prebreeding survival of barnacle geese Branta leucopsis in relation to fledgling characteristics. Journal of Animal Ecology 67:953-966.

Vandenbosch, R. 2003. Fluctuations of Vanessa cardui butterfly abundance with El Nino and Pacific 
Decadal Oscillation climatic variables. Global Change Biology 9:785-790.

Villard, M.-A., and B. A. Maurer. 1996. Geostatistics as a tool for examining hypothesized declines in migratory songbirds. Ecology 77:59-68.

Ward, D. H., A. Reed, J. S. Sedinger, J. M. Black, D. V. Derksen, and P. M. Castelli. 2005. North American Brant: effects of changes in habitat and climate on population dynamics. Global Change Biology 11:869-880.

Webster, M. S., and P. P. Marra. 2005. The importance of understanding migratory connectivity and seasonal interactions. Pages 199-209 in R. Greenberg and P. P. Marra, editors. Birds of Two Worlds. Johns Hopkins University Press, Baltimore, Maryland, USA.

Webster, M. S., P. P. Marra, S. M. Haig, S. Bensch, and R. T. Holmes. 2002. Links between worlds: unraveling migratory connectivity. Trends in Ecology and Evolution 17:76-83.

Weishampel, J. F., D. A. Bagley, and L. M. Ehrhart. 2004. Earlier nesting by loggerhead sea turtles following sea surface warming. Global Change Biology 10:1424-1427.

Wemmer, L. C., U. Ozesmi, and F. J. Cuthbert. 2001. A habitat-based population model for the Great Lakes population of the piping plover (Charadrius melodus). Biological Conservation 99:169-181.

Wilson, P. H. 2003. Using population projection matrices to evaluate recovery strategies for Snake River spring and summer chinook salmon. Conservation Biology 17:782-794.

Wiltschko, R., and W. Wiltschko. 2003. Mechanisms of orientation and navigation in migratory birds. Pages 433-456 in Berthold, P., E. Gwinner, and E. Sonnenschein, editors. Avian Migration. Springer-Verlag Berlin, Heidelberg, Germany.

Wood, C. C., and C. J. Foote. 1996. Evidence for sympatric genetic divergence of anadromous and nonanadromous morphs of sockeye salmon (Oncorhynchus nerka). Evolution 50:1265-1279.
Woodrey, M. S. 2000. Age-dependent aspects of stopover biology of passerine migrants. Studies in Avian Biology 20:43-52.

Yong, W., D. M. Finch, F. R. Moore, and J. F. Kelly. 1998. Stopover ecology and habitat use of migratory Wilson's warblers. Auk 115:829-842. 
APPENDIX 1. GLOSSARY OF TERMS. Key words used in this review and their meanings in the current context; references cited refer to literature from which the terms derived or were discussed, but definitions may not be identical.

Carry-over (i.e., individual-level seasonal interactions) - influence of events occurring in one season on individual survival or reproduction in a subsequent season (Norris 2005)

Density-dependence (i.e., population-level seasonal interactions) - population regulation based on limited resources, taking the form of negative relationships between seasonal abundance (or its drivers) and subsequent fitness; e.g., a linear negative relationship between breeding success and nonbreeding survival (Sillett and Holmes 2005, Webster and Marra 2005)

Environmental-level covariation - climate-driven covariation between consecutive seasonal vital rates

Migratory connectivity - links between breeding and nonbreeding populations, i.e., the degree to which individuals from the same breeding area share nonbreeding areas and vice versa (Webster et al. 2002)

Nonbreeding events - changes occurring during stationary or migratory nonbreeding seasons that could have implications for the fitness of seasonal migrants, e.g., habitat alteration, direct mortality threats, reduction in resource availability, interruption of migration route

Seasonal interactions - effects of events or changes in one season on survival or reproduction in another season; can occur at individual-level ,"carry-over", or population-level ,"density dependence" (Runge and Marra 2005)

Seasonal migrants - animals that make extended seasonal movements between geographically separated regions within their life cycle (e.g., Fig. 1); simply termed "migrants" in this review

Sensitivity or elasticity (of a vital rate) - absolute or proportional change in population growth rate $\lambda$ resulting from a change in that parameter (Caswell 2001) 


\section{APPENDIX 2. NONBREEDING SEASONS AND THE EVOLUTION OF MIGRATION}

Seasonal migration has evolved many times within diverse taxa (e.g., Pascual et al. 2001, Alerstam et al. 2003) and is expressed through a wide range of movement behaviours (Quinn and Myers 2004, Dingle 2006, Bolger et al. 2008). Migration will be favoured where the benefit gained from moving between habitats outweighs the fitness risks and energetic costs of the journey; seasonal and spatial variations in environmental conditions are therefore primary forces in its evolution (Fretwell 1972, Alerstam and Enckell 1979). Some theory suggests that migratory behaviour evolved primarily in response to the advantages of breeding in regions of seasonally high resource availability and safety for juveniles (Corkeron and Connor 1999, Friedland et al. 2005), especially where resources in the nonbreeding area were limited (Fretwell 1972, Cox 1968, 1985). Indeed, there is evidence today for competition during the nonbreeding season among many seasonal migrants (e.g., Pienkowski and Evans 1984, Perez-Tris and Telleria 2002, Ruggerone et al. 2003). Alternatively, the principal selection pressure might have been the survival advantage gained by individuals that migrated to less harsh, safer or more resource-rich environments after breeding (Lack 1968, Ketterson and Nolan 1982, Hebblewhite and Merrill 2007). Both scenarios involve the balancing of benefits and costs, in terms of energy acquisition and mortality risks, between breeding and nonbreeding seasons.

There is evidence that migratory behaviour continues to evolve in response to environmental changes or variation in nonbreeding habitats (Berthold et al. 1992). For instance, selection favours individual birds whose spring migration synchronizes breeding with peak resource availability (Kokko 1999, Drent et al. 2003, Bêty et al. 2004); heritability of migratory traits could thus allow migrants to adapt to changing climatic conditions experienced prior to breeding (Berthold and Pulido 1994, Both et al. 2005). Natural selection has also favored local adaptation to nonbreeding areas in migrating fish (e.g., Fraser and Bernatchez 2005), which could ultimately lead to speciation if it favored reproductive isolation between populations (Wood and Foote 1996). Nevertheless, the ability of migrants to adapt to rapid environmental changes may be also shaped by seasonal features such as migration distance, severity of nonbreeding habitat loss, correlations between seasonal environmental changes, or the strength of crossseasonal migratory connectivity (Dolman and Sutherland 1994, Sutherland 1998, Webster et al. 2002, Lemoine and Bohning-Gaese 2003, Both et al. 2005). 